\title{
GCLC Gene
}

National Cancer Institute

\section{Source}

National Cancer Institute. GCLC Gene. NCI Thesaurus. Code C38607.

This gene plays a role in the detoxification of endogenous reactive oxygen species. It is also involved in drug and xenobiotic metabolism. 